\title{
Optic Nerve Injury Alters Basic Fibroblast Growth Factor Localization in the Retina and Optic Tract
}

\author{
Sandra K. Kostyk, ${ }^{1,2}$ Patricia A. D'Amore, ${ }^{1,3}$ Ira M. Herman, ${ }^{4}$ and John A. Wagner ${ }^{5}$ \\ 'Department of Surgical Research, Children's Hospital, and ${ }^{2}$ Neurology Service, Massachusetts General Hospital, Boston, \\ Massachusetts 02114, ${ }^{3}$ Department of Pathology, Harvard Medical School, Boston, Massachusetts 02115, ${ }^{4}$ Program in \\ Cell, Molecular and Developmental Biology, Tufts University Health Sciences Schools, Boston, Massachusetts 02111, and \\ ${ }^{5}$ Department of Neurology and Neuroscience and Department of Cell Biology and Anatomy, Cornell University Medical \\ College, New York, New York 10021
}

Basic fibroblast growth factor (bFGF) is thought to be a trophic factor for several classes of neurons. Its distribution changes in response to cortical neural injury. We have determined the effect of injury to the optic nerve on localization of bFGF in the rodent retina and visual pathways. Our observations were confirmed by using different antisera and monoclonal antibodies. While photoreceptors normally contain virtually no bFGF, crushing the optic nerve causes a striking increase, over a period of several weeks, in the amount of bFGF in retinal photoreceptors. Since photoreceptors do not synapse directly upon the injured ganglion cells, intermediary cells must participate in the cascade of events that results in the elevated bFGF. In light of the observation that exogenous bFGF protects photoreceptors from photodamage (Faktorovich et al., 1992), this increase in bFGF in photoreceptors may explain, in part, why crushing the optic nerve protects photoreceptors against photodamage (Bush and Williams, 1991).

Whereas bFGF is constitutively found in glia in the optic nerve, little bFGF is found in glia in the optic tract. However, damage to the optic nerve increases bFGF in astrocytes in the optic tract. This change occurs within days, suggesting that a relatively direct signal may intervene between the injured axon and the adjacent glial cells. Thus, despite the fact that the optic nerve and optic tract are contiguous structures through which axons of retinal ganglion cells project, the glial elements in these structures express distinct properties, because of differences in either glial subclasses or microenvironment. We suggest that changes in neuronal and glial bFGF expression are part of a coordinated injury response that involves a dynamic interaction between neural cells and trophic factors. These changes may contribute to either a beneficial regenerative response or a pathological change that inhibits regeneration.

[Key words: basic fibroblast growth factor, retina, optic nerve, optic tract, fibroblast growth factors, CNS injury, photoreceptors, rat, mouse, glial cells]

\footnotetext{
Received Mar 24, 1993; revised Aug. 25, 1993; accepted Sept. 2, 1993.

We thank Christine Gallagher, Michael Nguyen, Erica Wheeler, and Richard Sullivan for excellent technical assistance. This research was supported in part by grants from the National Eye Institute, 5 K11 EY00311 to S.K.K., EY06454 to J.A.W. and P.A.D., and EY09033 and HL 35570 to I.M.H.

Correspondence should be addressed to Sandra K. Kostyk, M.D., Ph.D., Department of Surgical Research, Children's Hospital, 300 Longwood Avenue, Enders 10, Boston, MA 02115.
}

Copyright $\odot 1994$ Society for Neuroscience 0270-6474/94/14144i-09\$05.00/0
Basic fibroblast growth factor (bFGF) is a member of the fibroblast growth factor family. Members of this family of polypeptide growth factors have been shown to affect a wide range of mesenchymal and neuroectodermal cells, stimulating mitosis and chemotaxis in some cells and inducing differentiation in others (Burgess and Maciag, 1989; Baird and Bohlen, 1991). bFGF has been isolated in relatively high concentrations from brain and retinal tissue, suggesting a role in neural function (D'Amore and Klagsbrun, 1984; Gospodarowicz et al., 1984; Esch et al., 1985). The brain and retina are the only structures in the intact adult animal from which bFGF mRNA can be isolated in appreciable quantities (Mergia et al., 1986; Shimasaki et al., 1988; Emoto et al., 1990), indicating a need for continuous synthesis and perhaps a requirement for bFGF by mature neural cells. bFGF mRNA in other tissues is primarily detected during development, in hyperplastic or malignant cells, or after injury (Kimelman et al., 1988; Becker et al., 1989; Herbert et al., 1990; Mori et al., 1990; P.-T. Ku and P. A. D'Amore, unpublished observations).

There is convincing evidence that bFGF affects neural cells in vitro (see Wagner and Kostyk, 1990, for a review). bFGF has been shown to stimulate survival, differentiation, and/or neurite outgrowth in a wide variety of neural cells in culture (Morrison et al., 1986; Walicke et al., 1986; Unsicker et al., 1987; Lipton et al., 1988; Walicke, 1988). The application of exogenous bFGF in vivo has recently been shown to decrease neural cell loss in several models of CNS injury (Sievers et al., 1987; Anderson et al., 1988; Otto and Unsicker, 1990). There are also reports that the endogenous pattern of bFGF localization and expression changes in the CNS in response to traumatic cortical injury (Finklestein et al., 1988; Frautschy et al., 1991; Gómez-Pinilla and Cotman, 1992; Gómez-Pinilla et al., 1992; Logan et al. 1992).

In the visual system, bFGF has been implicated as a trophic factor that protects against injury and degeneration and stimulates regeneration. bFGF applied to a transected optic nerve triples the number of retinal ganglion cells (RGCs) surviving axotomy in the rat after $30 \mathrm{~d}$ (Sievers et al., 1987). When injected into the subretinal space or vitreous, bFGF delays photoreceptor degeneration in rats with inherited retinal dystrophy (Faktorovich et al., 1990) or phototoxicity (Faktorovich ct al., 1992). bFGF stimulates regeneration of the chick retina from pigment epithelial cells in vivo (Park and Hollenberg, 1989). In vitro, bFGF prolongs survival of RGC in retinal explants and stimulates differentiation of photoreceptors and other retinal cells 
(Bähr et al., 1989; Hicks and Courtois, 1992; Lillien and Cepko, 1992).

The pattern of endogenous bFGF expression within the visual system following injury, however, has not been explored. In the following studies we use immunohistochemical techniques to describe the normal distribution of bFGF in the mouse retina, optic nerve, and optic tract and the changes in its distribution following optic nerve lesion.

\section{Materials and Methods}

Optic nerve injury. Four- to eight-week-old C57 black mice were anesthetized with intraperitoneal injections of Avertin $(0.02 \mathrm{cc} / \mathrm{gm})$. Optic nerves were exposed and crushed intraorbitally $2-4 \mathrm{~mm}$ posterior to the optic disk between fine forceps for 30-60 sec. In sham-operated controls the optic nerve was similarly exposed but not crushed. Retina, optic nerves, and optic tracts from unoperated animals and from the sides opposite the lesions served as controls. Animals were killed at various time points between $3 \mathrm{~d}$ and 6 weeks following the surgical procedures. At least two animals were killed at each of the following time points: $2,3,4$, and 5 weeks. To control for the possibility that the retro-orbital optic nerve crush injury was affecting the retina by damaging the retinal blood supply, seven adult Sprague-Dawley rats that had one optic nerve sectioned just anterior to the optic chiasm were purchased from Zivic-Miller Laboratories (Zelienople, PA). The optic nerve in the rats was approached intracranially through the roof of the mouth so as not to affect the retinal vasculature (Madison et al., 1984). Two animals were killed at each of three time points: 4,6 , and 7 weeks postoperatively. An additional animal was killed at 5 weeks. Two shamoperated animals were also purchased. Retinas from these animals were processed as for the mouse tissue. All procedures involving mice and rats adhered to the policy and guidelines of the Society for Neuroscience for care and use of animals in neuroscience research.

Tissue preparation. Animals were anesthetized and then perfused through the left ventricle with phosphate-buffered saline (PBS), $\mathrm{pH} 7.4$, followed by $4 \%$ paraformaldehyde in $0.1 \mathrm{M}$ sodium phosphate buffer, $\mathrm{pH}$ 7.4. The retinas and individual pieces of nerves were postfixed for $30-60 \mathrm{~min}$ and then equilibrated in 30\% sucrose/PBS for several hours at $4^{\circ} \mathrm{C}$. Brain tissue was postfixed for $2-4 \mathrm{hr}$ and then equilibrated in sucrose overnight. Tissue sections were cut in a cryostat at $-22^{\circ} \mathrm{C}$. Sections of 4-6 $\mu \mathrm{m}$ were used for immunofluorescence analysis. Thicker $(12 \mu \mathrm{m})$ sections were used for peroxidase reactions and $35 \mu \mathrm{m}$ sections were occasionally collected and processed as floating sections. Sections were mounted on double-subbed glass slides.

Immunolocalization of bFGF and glial fibrillary acidic protein. As there has been some controversy in the literature regarding the immunostaining pattern of $\mathrm{bFGF}$ in the retina and brain (Hanneken and Baird, 1992), immunohistochemical staining to localize bFGF was carried out using several different preparations of antibodies on tissue prepared by identical fixation techniques. The antibody we used most frequently in these studies was a well-characterized rabbit polyclonal immunoglobulin (IgG) raised against human recombinant bFGF (Healy and Herman, 1992). This anti-bFGF IgG was used at dilutions between 2 and $10 \mu \mathrm{g} / \mathrm{ml}$. A subset of slides was stained with an affinity-purified fraction of this IgG obtained by passage over a human recombinant bFGF-Affigel column. No significant differences were found in the staining between these two sets of slides, although the level of diffuse background staining was decreased using the affinity-purified labeled IgG. Control sections were stained with nonimmune IgG, preimmune sera, or bFGF antiserum that was preabsorbed onto a bFGF-Affigel column Other bFGF antibodies that were used included a monoclonal antibody to bovine bFGF (type I, Upstate Biotechnology Inc., Lake Placid, NY) a monoclonal to human recombinant bFGF (kindly donated by Takeda Chemical Industries, Ltd., Osaka, Japan), and an affinity-purified rabbit polyclonal antibody to bovine bFGF (R\&D Systems, Minneapolis, MN) The staining patterns obtained with all of these bFGF antibodies were similar.

For immunostaining, tissue sections were successively incubated as follows: $10 \%$ normal goat serum (NGS; Sigma)/PBS for $30 \mathrm{~min}$ at room temperature (RT); primary antisera or control solution in $1 \%$ NGS, $0.3 \%$ Triton $\mathrm{X}-100$, for $1-24 \mathrm{hr}$ at $\mathrm{RT}$ or at $4^{\circ} \mathrm{C}$; secondary antisera, biotinylated goat anti-rabbit (Vector Labs, Burlingame, CA) or biotinylated goat anti-mouse (Pierce, Rockford, IL), in $1 \%$ NGS, $0.3 \%$ Triton $\mathrm{X}-100$ for $\mathrm{I} \mathrm{hr}$ at RT; avidin-biotin complex (Vector Labs) for $1 \mathrm{hr}$ at RT; $0.05 \%$ diaminobenzidine (DAB; Sigma, St. Louis, MO) in $0.01 \%$ hydrogen peroxide, $50 \mathrm{~mm}$ Tris- $\mathrm{HCl}$ for $1-3 \mathrm{~min}$ at RT. For doublestaining studies, the biotinylated secondary antibody was followed with a 1:100 solution of Streptavidin-linked fluorescein or Texas red (Amersham, Arlington Heights, IL) for $1 \mathrm{hr}$ at RT. Sections were then exposed to a 1:400 dilution of mouse monoclonal anti-bovine glial fibrillary acidic protein (GFAP; Boehringer Mannheim, Indianapolis, IN), an astrocyte marker, for $1 \mathrm{hr}$ at RT followed by a $1 \mathrm{hr}$ incubation with fluorescein- or Texas red-conjugated anti-mouse IgG. Each of these incubations included appropriate washings with PBS between steps. Coverslips were applied and slides were then examined by light and fluorescence microscopy.

\section{Results}

\section{Localization of $b F G F$ in the normal retina}

$\mathrm{bFGF}$ is found in relatively high concentrations in the adult retina (D'Amore and Klagsbrun, 1984; Baird et al., 1985). If it is acting in the retina as a neurotrophic factor, then one might expect a change in bFGF distribution after neuronal injury in the retina.

In the adult mouse retina, intense bFGF immunoreactivity was present in the RGC layer (Fig. 1a). The morphology of the cells expressing bFGF in this layer suggested they were astrocytes. This was confirmed by showing that the majority of the cells that were inmunoreactive for bFGF (Fig. 1c) also expressed GFAP (Fig. 1f). Occasional staining was seen in the blood vessels in this layer. Intense bFGF labeling was also observed in scattered cells in the inner nuclear layer (INL; Fig. 1a). The morphological appearance of the cells that stained in the INL suggests that many of these cells are Mueller cells. Sections similarly processed but without application of the primary antibody (Fig. $1 b$ ) or using preimmune or preabsorbed antibody showed no specific labeling. A similar staining pattern was seen with the two monoclonal antibodies (one of which is shown in Fig. 1a) and also the polyclonal antibody to human recombinant bFGF. However, the affinity-purified polyclonal antibody against bovine bFGF (R\&D) did not label the cells in the INL as intensely as the other antibodies. Connolly et al. (1992) have also noted some antibody-dependent variation in

Figure 1. bFGF immunolocalization in the normal mouse retina and in the retina following optic nerve injury. $a$, The typical pattern of bFGF immunoreactivity in a normal adult mouse retina. Prominent cell body labeling visualized with Texas red is seen in the RGC layer and the INL. $b$. Section of normal retina processed similarly to sections in $a$ and $d$ except for the omission of application of the primary antibody. $c$, bFGFpositive cell (arrowhead) in the RGC layer of a normal retina visualized with a fluorescent-linked antibody. $d$, bFGF immunolabeling in a retina 3 weeks following a retro-orbital optic nerve crush lesion. Note the intense increase in staining in the ONL as compared to the level of staining in the ONL of the intact retina in $a$. $e$. Higher-magnification image of the INL and ONL of the retina photographed in $d$. The labeled cells in the INL, in the lower portion of the picture, show intense label over what appears to be a Mueller cell nucleus and cell body. The injury-induced staining pattern in the ONL shows little or no nuclear staining but rather displays a ring or doughnut-like labeling pattern. $f$, Processes of the same cell as in $c$ labeled with an antibody to GFAP linked to Texas red. In $a, d$, and $e$ bFGF was localized using a monoclonal antibody to bovine bFGF purchased from Upstate Biotechnology Inc. (type 1). In $c$, bFGF was localized using the rabbit polyclonal IgG to human recombinant bFGF prepared in our laboratories. $I$, inner nuclear layer; $O$, outer nuclear layer; $R$, retinal ganglion cell layer. Magnification: $a, b$, and $d, 343 \times ; c$ and $f$, $548 \times ; e, 858 \times$ 
a

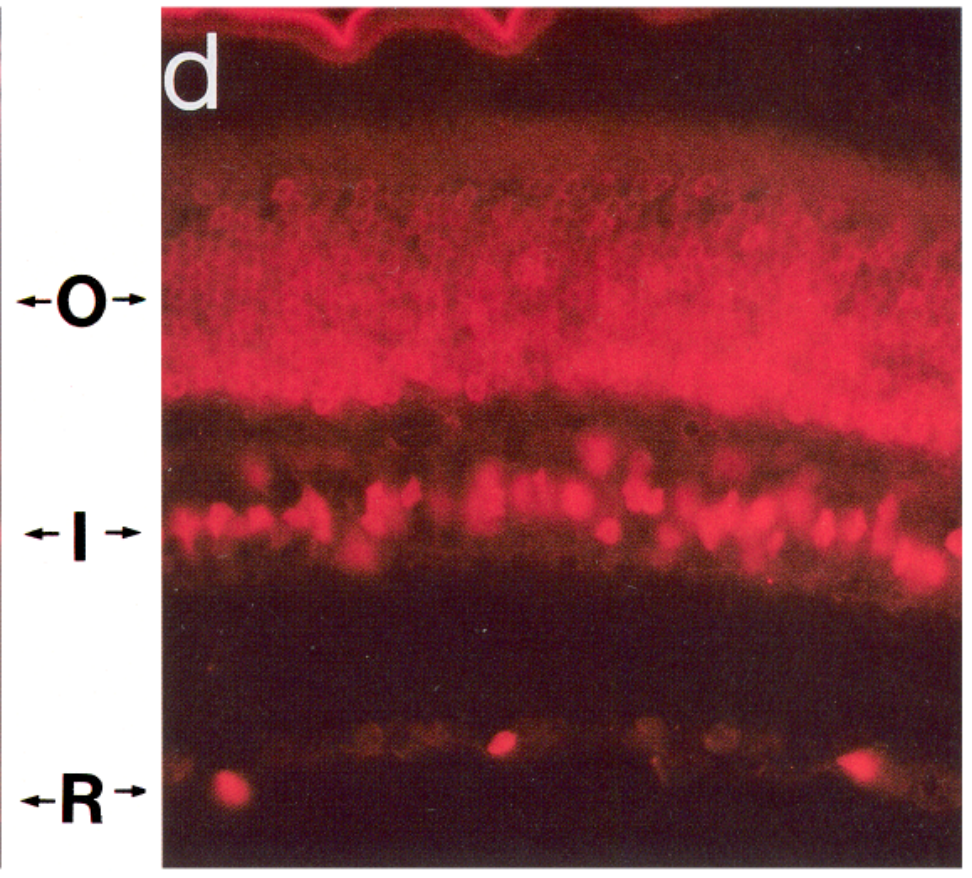

b
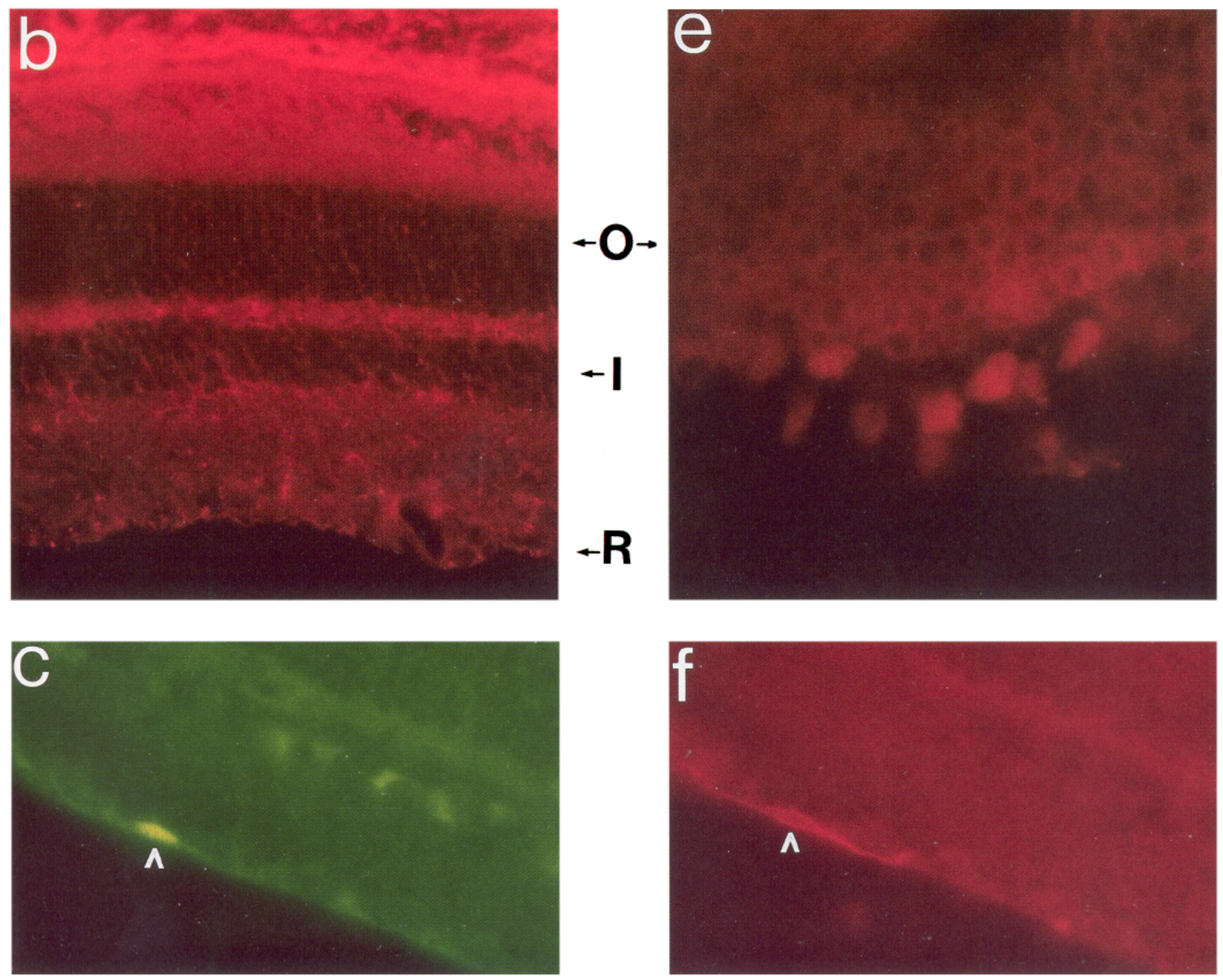

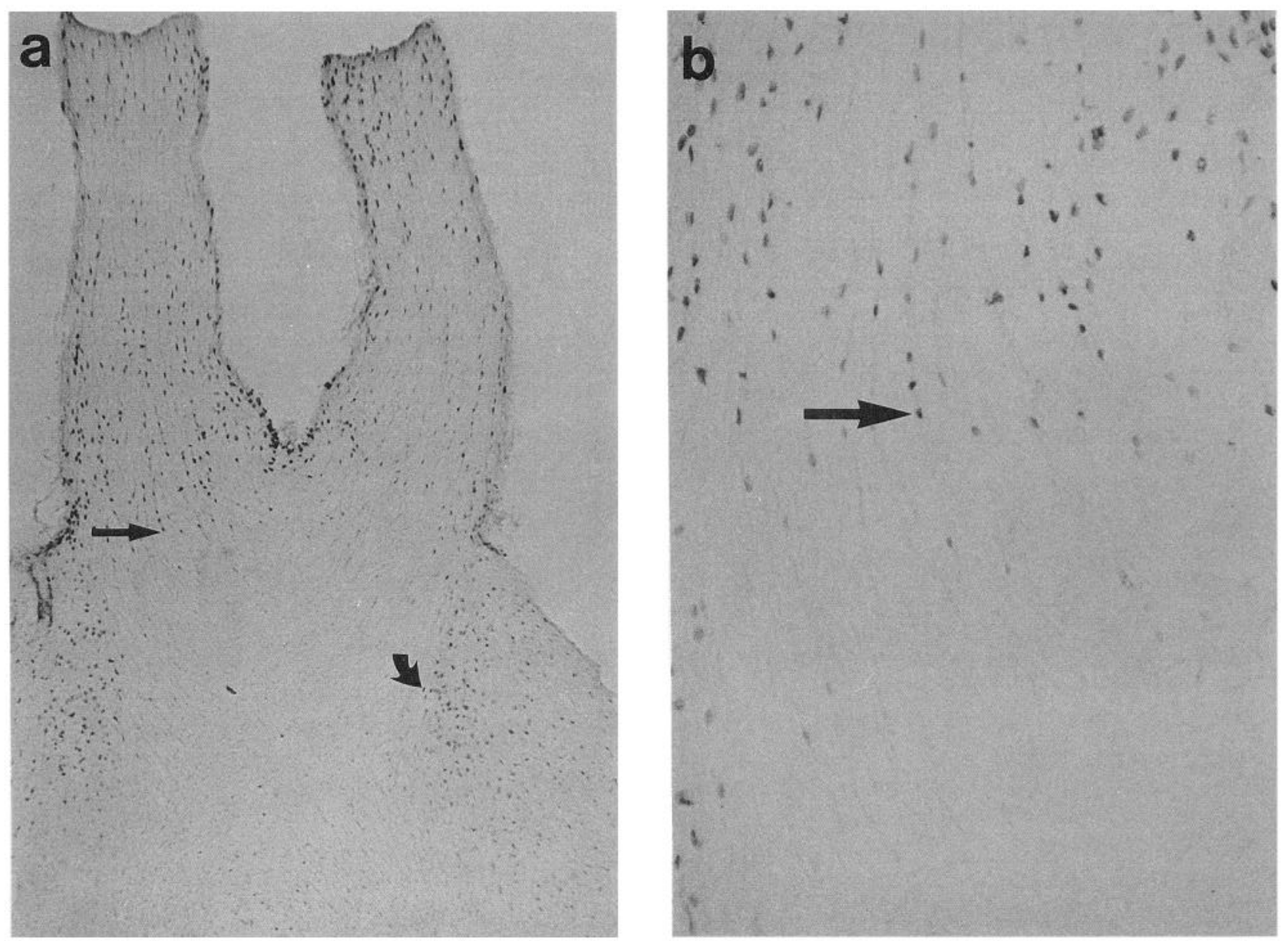

Figure 2. bFGF staining in the mouse optic nerve and chiasm. $a$, Both optic nerves show intense bFGF labeling. Little or no staining is seen once the fibers pass into the chiasm. Straight arrows in $a$ and $b$ point to the identical labeled cells near the beginning of the chiasm. Curved arrow points out positively stained cells in the hypothalamus adjacent to the optic chiasm. $b$. Higher-magnification view of $a$ showing the sharp demarcation between the optic nerve and the chiasm with respect to the pattern of glial cell staining. The arrow identifies the same region in the two photographs. bFGF was localized with the Upstate Biotechnology Inc. monoclonal antibody to bFGF and visualized with HRP/DAB. Magnification: $a, 21.6 \times$; $b, 68 \times$.

the intensity of bFGF immunolabeling in cells in the INL of the rat retina. We noted a similar localization pattern of bFGF in the retina in normal animals, in sham-operated animals, and in the intact eye after a well-defined crush injury to the optic nerve of the opposite eye.

\section{Injury to the optic nerve alters $b F G F$ localization in the retina}

Within 2 weeks of an intraorbital crush lesion of the optic nerve, there was a remarkable change in the pattern of bFGF immunoreactivity in the retina. The most profound change was the appearance of a new and intense pattern of labeling throughout the outer nuclear layer (ONL; compare Fig. $1 a, d$ ). This layer of the retina is composed primarily of the cell bodies and nuclei of the rods and cones and it shows little, if any, bFGF immunoreactivity in the normal retina. Increased ONL bFGF immunoreactivity was evident in all animals killed 7 or more days following the crush injury. The intensity of labeling peaked at about 3 weeks and persisted for at least 6 weeks. Following the crush lesion, there was persistent labeling of cells in the INL and staining of astrocytes in the RGC layer that was not dramatically different from that seen in the normal retina. The pattern of staining in the cells of the ONL differed from that seen in the INL and RGC layer. Whereas the nucleus and the surrounding cytoplasm were labeled in cells of the INL and RGC layer, the immunolabeling pattern in the cells of the ONL appears to exclude the cell nucleus and delineates the perinuclear cytoplasm or cell membrane (Fig. 1e). All antibodies used to localize $b F G F$ showed an identical pattern of bFGF induction in the ONL of the retina following optic nerve injury. In most sections of retina following optic nerve lesion, there was also a slight increase in bFGF labeling along the inner limiting membrane, but it is not possible to determine at the level of resolution of the light microscope whether this increase was due to an increase in $\mathrm{bFGF}$ in the extracellular matrix, astrocyte processes, or Mueller cell end feet.

Because the observed change in retinal bFGF localization might be due, in part, to ischemia caused by occlusion of the central retinal artery, we also examined the effect of intracranial optic nerve section on bFGF distribution in seven rats and two sham-operated controls. This approach to the optic nerve avoids any interruption of retinal blood supply (Madison et al., 1984; Tsang et al., 1985). The pattern of bFGF localization in the retina on the intact side was similar to that seen in the mouse, except that since the animals were amelanotic, the previously 
described nuclear staining pattern in the retinal pigment epithelial cells could be visualized (Connolly et al., 1992; Gao and Hollyfield, 1992). The pattern of induction of bFGF immunoreactivity in the ONL on the lesioned side was identical to that seen in the mouse except for the fact that the time course for the induction process was slightly longer (data not shown). The increased ONL bFGF was not maximum until nearly 6 weeks in the rat versus 3 weeks after the lesion in the mouse.

\section{Optic nerve and optic tract differ in their distribution of $b F G F$}

Surprisingly, the distribution of bFGF immunoreactivity in the intact optic nerve was dramatically different from the pattern in the optic tract, despite the fact that these two structures carry continuous axons from the same RGCs. The optic nerve is that part of the optic pathway that contains the RGC axons as they exit from the back of the eye. In the mouse, the RGC axons then, for the most part, cross in the optic chiasm (Dräger and Olsen, 1980). Once past the chiasm, the axons form the optic tract, a pathway that runs along the base of the diencephalon where some of the axons terminate. The tract then continues on to the mesencephalon where the remaining axons synapse.

In the optic nerve, there was intense bFGF immunoreactivity over glial cell bodies (Fig. $2 a, b$ ). These bFGF-positive cells were regularly shaped and aligned in linear arrays. In nonlesioned animals, once the RGC axons passed into the chiasm and continued into the optic tract, they were no longer associated with bFGF-immunolabeled glial cells (Fig. $2 a, b$ ). Thus, the presence of bFGF is not a defining feature of glial cells in this pathway, but is rather a function of the specific location of these cells within the pathway. Astrocytes at the base of the brain immediately adjacent to, but not within, the optic chiasm were positive for bFGF (Fig. $2 a$ ).

\section{bFGF immunoreactivity is increased in the optic tract following injury of the optic nerve}

Following optic nerve crush, bFGF immunoreactivity was still present in glial cells in the optic nerve both proximal and distal to the crush site. However, in the lesioned nerve, the labeled cells were no longer regularly shaped or aligned in linear arrays (compare Fig. $3 b, c$ ). Instead, cell bodies of labeled cells were larger and had more irregular borders. The loss of linear array and cellular homogeneity was associated with the progression of RGC axonal degeneration and glial scar formation in the injured nerve (Fig. 3c).

Although there were virtually no bFGF-immunoreactive cells in the normal optic tract (e.g., the tract ipsilateral to the injury or the tract from an intact animal; Fig. $4 a$ ), there were intensely labeled cells in the optic tract carrying the injured RGC axons within 3-6 d following the crush injury (Fig. $4 b$ ). Double fluorescence staining for bFGF and GFAP demonstrated that most, if not all, of these cells were astrocytes (Fig. 5). Within the injured optic tract, however, not all astrocytes stained for bFGF, suggesting that there is heterogeneity in responsiveness to RGC axon injury among astrocytes in the optic tract. For the most part, little labeling was seen in the optic tract ipsilateral to the lesioned nerve. The occasional labeled cells that were noted in the ipsilateral optic tracts were probably related to axonal degeneration of the small proportion of the axons that project to the ipsilateral tract, rather than cross to the contralateral side in the chiasm in the mouse (Dräger and Olsen, 1980).

The major target nuclei of the optic tract, the dorsal lateral
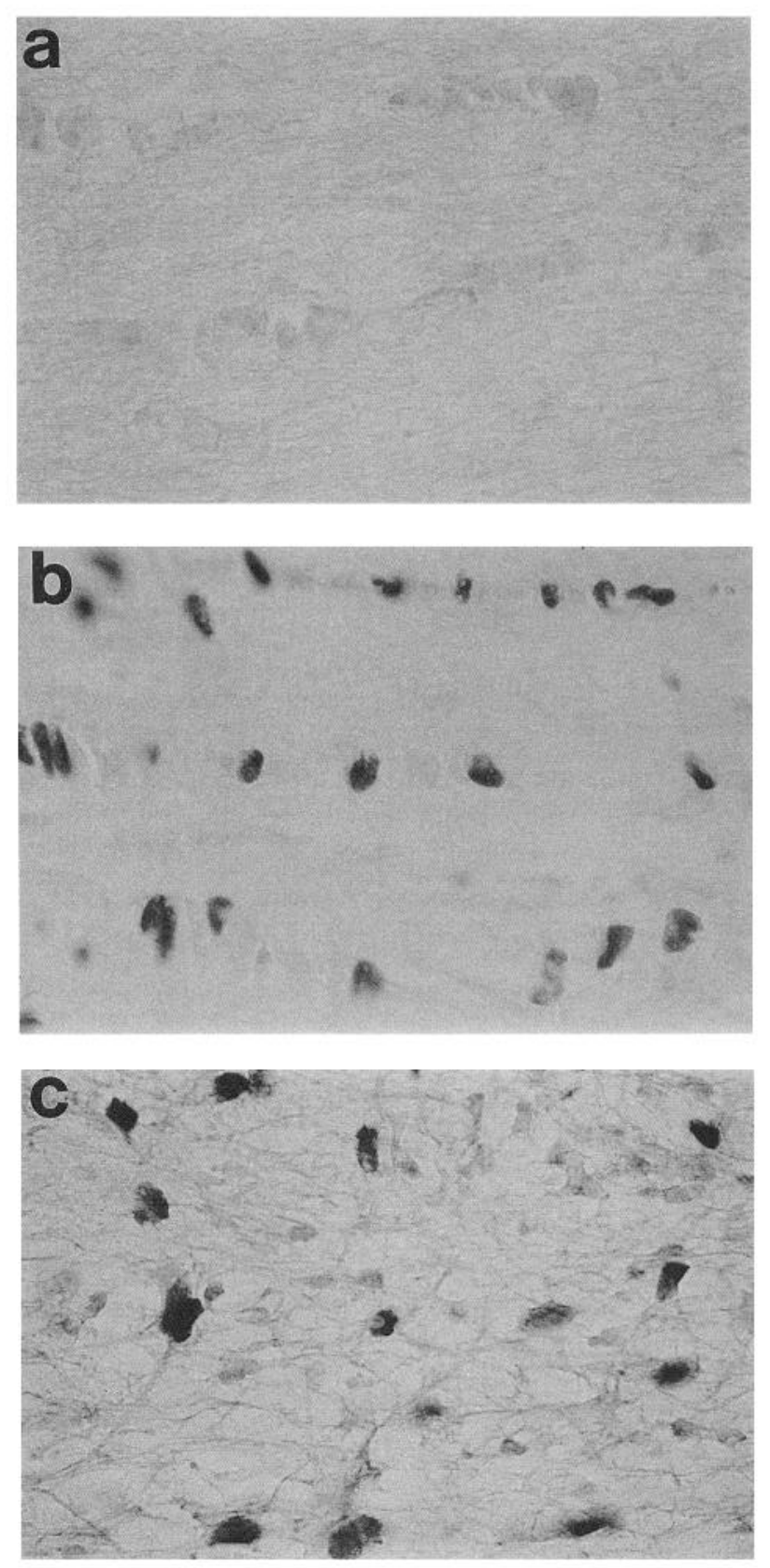

Figure 3. bFGF immunohistochemical staining in the normal and lesioned mouse optic nerve. $a$, Optic nerve stained with bFGF-preabsorbed polyclonal rabbit anti-human bFGF IgG. $b$, The pattern of bFGF labeling in the intact optic nerve with the polyclonal anti-bFGF IgG from the same source as used in $a$. Note the regular, almost linear array of labeled glial cells. $c$, Following optic nerve crush, the linear pattern of immunolabeled cells is disrupted and there is greater heterogeneity of cell size and shape. The same staining pattern was seen with all four antibodies used. Sections exposed to preimmune serum or secondary antibodies alone appeared similar to $a$ and did not show a specific pattern of staining. Magnification, $180 \times$.

geniculate nucleus and the superior colliculus, were also examined for changes in bFGF immunoreactivity patterns. Although bFGF-immunoreactive astrocytes were seen along the entire course of the degenerating optic tract, there was no striking change in either the location or intensity of bFGF staining within either nucleus from 3 d to 6 weeks following injury (data not shown). 

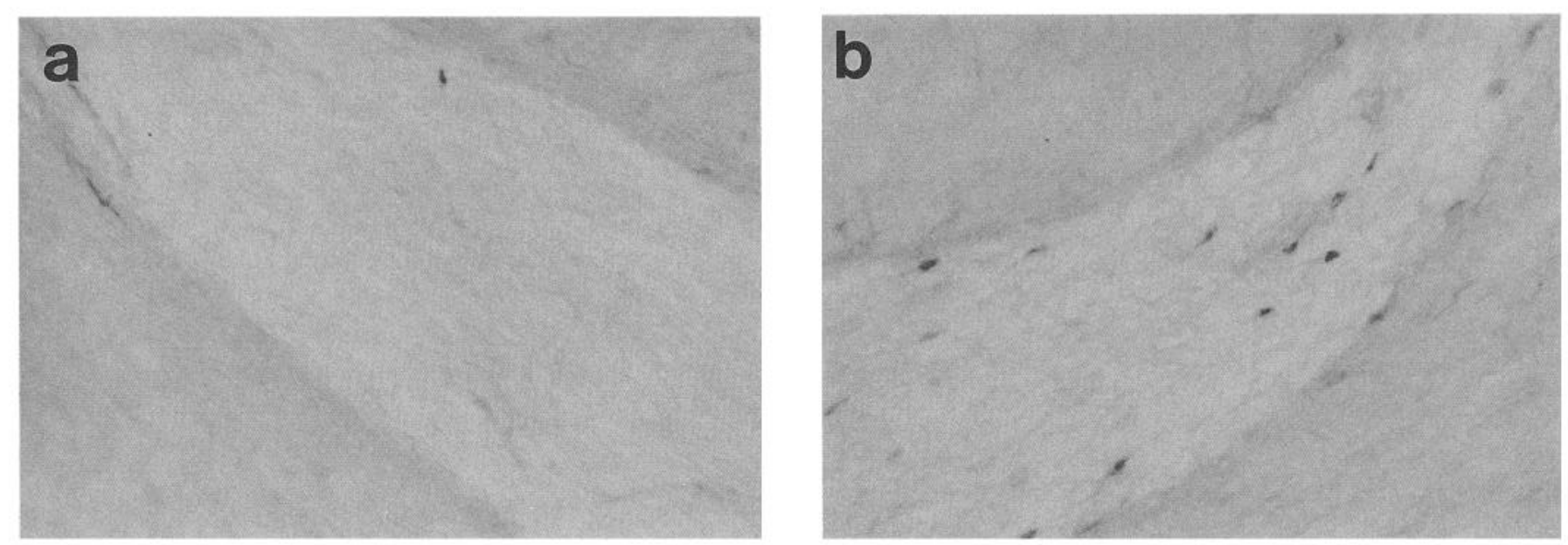

Figure 4. Optic nerve crush injury increases bFGF immunoreactivity in the optic tract. $a$, Coronal section through a mouse optic tract ipsilateral to the injured optic nerve (i.e., the tract containing intact RGC axons) shows little bFGF staining. The dark spot in the upper portion of the tract is an artifact. Both optic tracts in sham-operated animals appeared similar. $b$, Three weeks after crush injury, bFGF immunolabeling was prominent in the optic tract contiguous with the crushed optic nerve. $a$ and $b$ were both stained with the rabbit polyclonal antibody to human recombinant bFGF. Labeled cells were visualized with HRP/DAB. Magnification, $76 \times$.

\section{Discussion}

The changes in the pattern of bFGF immunoreactivity in both CNS neurons and glia following injury to the optic nerve suggest that bFGF interacts with both cell types to coordinate the response to axonal injury in the visual system. The most dramatic change in bFGF within the visual system following optic nerve injury was the increase in bFGF immunoreactivity in the ONL of the retina. This layer contains the nuclei and cell bodies of the photoreceptors. Photoreceptors do not send processes out of the retina into the optic nerve, nor do they synapse directly upon the lesioned RGCs. The change in bFGF in photoreceptors, despite their lack of direct contact with the injured cells, raises the question of how information about the damage to the optic nerve is communicated to this region of the retina. The observed change may result from a retrograde transsynaptic signal from the RGCs through an intermediary cell, such as bipolar or Mueller cells, to the photoreceptors, or alternatively, the signal may arise from loss of an efferent signal transmitted through a centrifugal pathway in the optic nerve (Itaya, 1980; Ohno, 1980; Dräger et al., 1984; Hoogland et al., 1985; Labandeira-Garcia, 1988; Owusu-Yaw et al., 1992).

The increase in bFGF immunoreactivity in the photoreceptors of the ONL may explain an interesting paradox. Sectioning the optic nerve in rats has been found to protect photoreceptors from photodamage by constant light (Bush and Williams, 1991). Though it is not obvious why damaging the optic nerve should protect the photoreceptors, there is reason to suspect that bFGF may play a role in this phenomenon. bFGF injected intravitreally protects photoreceptors in rats from degeneration due to either an inherited degenerative disorder (Faktorovich et al., 1990) or photodamage (Faktorovich et al., 1991). In light of our observation that optic nerve injury leads to an increase in bFGF, we suggest that the protection of photoreceptors from light damage following optic nerve section may be due to the increased endogenous bFGF available to the photoreceptors. Although our findings are consistent with the hypothesis that optic nerve section-induced increases in bFGF protect photoreceptors from photodamage by increasing endogenous bFGF, no direct causal role has been demonstrated.
Immunohistochemical analysis cannot determine whether the elevated ONL bFGF is a result of increased bFGF production by photoreceptors versus increased uptake of bFGF from an exogenous source. Results of in situ hybridization studies in normal adult rat retina localize bFGF mRNA to the inner segments of the photoreceptors, supporting the theory that the increased bFGF is the result of bFGF synthesis by the photoreceptors (Noji et al., 1990). This suggests that these cells constitutively express bFGF message and may modulate production of bFGF in response to optic nerve injury. However, the possibility that the elevated photoreceptor bFGF is the result of receptor binding and internalization of bFGF from another source is suggested by the fact that rod outer segments are known to have FGF receptors (Plouet et al., 1988; Mascarelli et al., 1989). Other retinal cells that are known to contain bFGF in the normal state, such as pigment epithelial cells (Schweigerer et al., 1987; Sternfeld et al., 1989; Bost et al., 1992; Ishigooka et al., 1992), INL cells, or retinal astrocytes, may be the source of bFGF after injury. Alternatively, bFGF may be released from dying RGCs.

Unlike the staining pattern seen in the astrocytes and INL cells, the staining pattern of bFGF in the ONL cells appears to exclude the cell nucleus. This may reflect receptor, cell surface binding, or perinuclear cytoplasmic bFGF. Exogenous bFGF applied to neurons and astrocytes in vitro has been shown to be internalized and localized to the perinuclear cytoplasm and also translocated to the nucleus (Walicke and Baird, 1991). The difference in bFGF localization between the photoreceptors and the glial cells suggests that bFGF may not have the same function in both.

Increased bFGF immunoreactivity in the ONL was also demonstrated in adult rats following intracranial optic nerve injury. The retinal blood supply is not affected when injury is induced by this approach (Madison et al., 1984; Tsang et al., 1985). Thus, this finding confirms that the increase in retinal bFGF is not attributable to disruption of retinal blood flow. It also demonstrates that the change in bFGF localization is not unique to one species. The only difference noted between the induction of bFGF in the ONL of mice with retro-orbital optic nerve injuries and rats with the intracranial lesions was the slightly longer time interval noted in the rat before the appearance of 
the increased bFGF labeling (5-6 weeks vs $2-3$ weeks). Though this finding may reflect species-specific differences, it is more likely attributable to the fact that the optic nerve injury in the rat was several millimeters farther away from the RGC body than the mouse injury. It has previously been shown that the farther away from the cell body an axon is injured, the longer it takes for degenerative changes to occur in the cell body and the more likely it is that a greater proportion of RGC will survive axotomy (James, 1933; Leimfelder, 1940).

\section{Variations in glial cell bFGF immunolabeling}

The optic nerve and optic tract, contiguous structures consisting of RGC axons, glial cells, and connective tissue, serve as the pathway for RGC axons coursing from the retina to the brain. Nonetheless, the pattern of bFGF labeling in these two structures was very different. Whereas there was intense bFGF labeling of glia in the optic nerve, there was virtually no staining in the intact optic tract. Thus, there may be some important differences in the role of bFGF or the way bFGF glial expression is regulated before and after the decussation in the chiasm. Our findings are consistent with the suggestion that there may be variations in the properties of astrocytes in different regions of the brain (Cholewinski et al., 1988; Shinoda et al., 1989). In support of this, in vitro studies have demonstrated that astrocytes from different areas of the brain differ in their morphological and biochemical responses to bFGF (Perraud et al., 1988, 1990; Engele and Bohn, 1992).

Astroglia in the optic tract have increased levels of bFGF following optic nerve injury. This result is similar to that observed in traumatic cortical injury where elevated astroglial bFGF and bFGF mRNA have been demonstrated (Finklestein et al., 1988; Frautschy et al., 1991). The increased astroglial bFGF in the optic tract is in cells a significant distance from the site of injury, along the full extent of the degenerating RGC pathway. The mechanism responsible for increased bFGF in cells distant from the injury is unknown, but a primary signal presumably originates from the degenerating RGC axons. Despite the appearance of bFGF within the tract following injury, the number of positive cells is still small compared to the total number of astroglial cells in the tract. Most of the glial cells in the optic tract were not bFGF immunoreactive, suggesting heterogeneity among astrocytes within the optic tract. As is true in the retina, it is possible that the increased level of bFGF in the optic tract is due to either increases in bFGF expression or accumulation. Since astrocytes express both bFGF protein and FGF receptors (Frautschy et al., 1991; Walicke and Baird, 1991; Logan et al., 1992; Takami et al., 1992), bFGF may be involved in an autocrine loop that is responsible for reactive changes in these astrocytes.

The results of this study indicate the wide-ranging and varied roles that bFGF may play in the response of the visual system to injury. These results may have important implications for future efforts to minimize the extent of deficit after injury and to maximize regenerative potential. The difference in the pattern of localization of bFGF in glial cells in the optic nerve and optic tract suggests that different interventions may be more appropriate to minimize injury and stimulate regeneration at various points along a regenerating pathway. The induction of bFGF immunoreactivity in the photoreceptors several weeks after injury emphasizes the importance of considering cells that are multiple synapses away from the directly injured cells. The increase in bFGF may be an indication of delayed cell injury. If
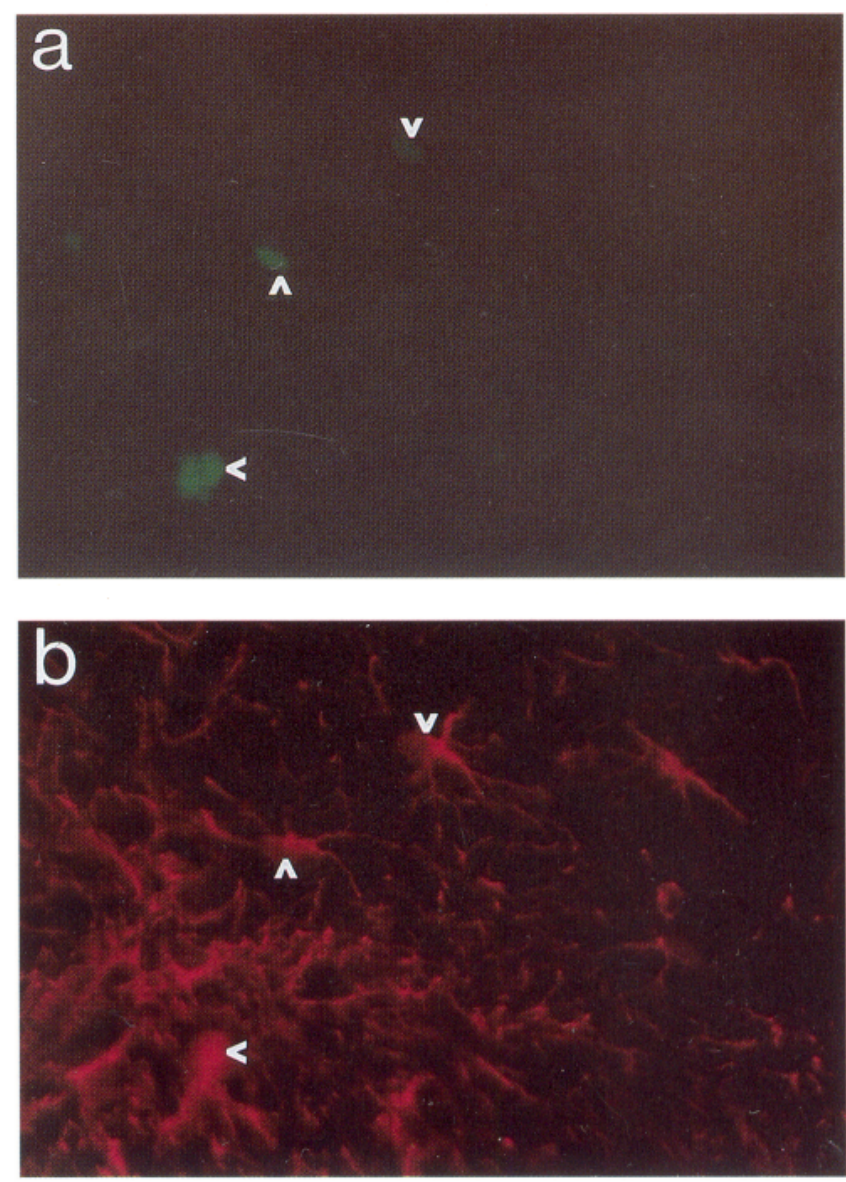

Figure 5. Double-labeled astrocytes in the optic tract following optic nerve injury. $a$, Optic tract cells labeled with a polyclonal rabbit antihuman IgG to bFGF visualized with a fluorescent marker. $b$, The same section as in $a$ labeled with an antibody to GFAP visualized with Texas red. Arrowheads identify identical cells in $a$ and $b$.

so, such delayed injury might be prevented by application of bFGF or other factors directly to the eye in an interim period while efforts are underway to stimulate optic nerve regeneration.

\section{References}

Anderson KJ, Dam D, Lee S, Cotman CW (1988) Basic fibroblast growth factor prevents death of lesioned cholinergic neurons in vivo. Nature 332:360-361

Bähr M, Vanselow J, Thanos S (1989) Ability of adult rat ganglion cells to regrow axons in vitro can be influenced by fibroblast growth factor and gangliosides. Neurosci Lett 96:197-201.

Baird A, Bohlen P (1991) Fibroblast growth factors. In: Peptide growth factors and their receptors II (Sporn MB, Roberts AB, eds), pp 369406. New York: Springer.

Baird A, Esch F, Gospodarowicz D, Guillemin R (1985) Retina- and eye-derived endothelial cell growth factors: partial molecular characterization and identity with acidic and basic fibroblast growth factors. Biochemistry 24:7855-7860.

Becker D, Meier CB, Herlyn M (1989) Proliferation of human malignant melanomas is inhibited by antisense oligodeoxynucleotides targeted against basic fibroblast growth factor. EMBO J 8:3685-3691.

Bost LM, Aotaki-Keen AE, Hjelmeland LM (1992) Coexpression of FGF- 5 and bFGF by the retinal pigment epithelium in vitro. Exp Eye Res 55:727-734.

Burgess WH, Maciag T (1989) The heparin-binding (fibroblast) growth factor family of proteins. Annu Rev Biochem 58:575-606.

Bush RA, Williams TP (1991) The effect of unilateral optic nerve section on retinal light damage in rats. Exp Eye Res 52:139-153. 
Cholewinski AJ, Hanley MR, Wilkin GP (1988) A phosphoinositidelinked peptide response in astrocytes: evidence for regional heterogeneity. Neurochem Res 13:389-394.

Connolly SE, Hjelmeland LM, LaVail MM (1992) Immunohistochemical localization of basic fibroblast growth factor in mature and developing retinas of normal and RCS rats. Curr Eye Res 11:10051017.

D'Amore PA, Klagsbrun M (1984) Endothelial mitogens derived from retina and hypothalamus: biological and biochemical similarities. J Cell Biol 99:1545-1549.

Dräger UC, Olsen JF (1980) Origins of crossed and uncrossed retinal projections in pigmented and albino mice. J Comp Neurobiol 191: $383-412$.

Dräger UC, Edwards DL, Barnstable CJ (1984) Antibodies against filamentous components in discrete cell types of the mouse retina. $\mathrm{J}$ Neurosci 4:2025-2042.

Emoto N, Gonzalez AM, Walicke PA, Wada E, Simmons DM, Shimasaki A, Baird A (1990) Identification of specific loci of basic fibroblast growth factor synthesis in the rat brain. Growth Factors 2:21-29.

Engele J, Bohn MC (1992) Effects of acidic and basic fibroblast growth factors (aFGF, bFGF) on glial precursor cell proliferation: age dependency and brain region specificity. Dev Biol 152:363-372.

Esch F, Ueno N, Baird A, Hill F, Denoroy L, Ling N, Gospodarowicz $D$, Guillemin R (1985) Primary structure of bovine brain acidic fibroblast growth factor (FGF). Biochem Biophys Res Commun 133: 554-562.

Faktorovich EG, Steinberg RH, Yasumura D, Matthes MT, LaVail MM (1990) Photoreceptor degeneration in inherited retinal dystrophy delayed by basic fibroblast growth factor. Nature 347:83-86.

Faktorovich EG, Steinberg RH, Yasumura D, Matthes MT, LaVail MM (1991) Photoreceptor rescue in retinal degenerations by basic fibroblast growth. In: Retinal degenerations (Anderson RE, Hollyfield JG, LaVail MM, eds), pp 10l-108. Boca Raton: CRC.

Faktorovich EG, Steinberg RH, Yasumura D, Matthes MT, LaVail MM (1992) Basic fibroblast growth factor and local injury protect photoreceptors from light damage in the rat. J Neurosci 12:3554-3567.

Finklestein SP, Apostolides PJ, Caday CG, Prosser J, Philips MF, Klagsbrun M (1988) Increased basic fibroblast growth factor (bFGF) immunoreactivity at the site of focal brain wounds. Brain Res 460:253259.

Frautschy SA, Walicke PA, Baird A (1991) Localization of basic fibroblast growth factor and its mRNA after CNS injury. Brain Res 553:291-299.

Gao H, Hollyfield JG (1992) Basic fibroblast growth factor (bFGF) immunolocalization in the rodent outer retina demonstrated with an anti-rodent antibody. Brain Res 585:355-360.

Gómez-Pinilla F, Cotman CW (1992) Transient lesion-induced increase of basic fibroblast growth factor and its receptor in layer VIb (subplate cells) of the adult rat cerebral cortex. Neuroscience 49:771780.

Gómez-Pinilla F, Lee JW-K, Cotman CW (1992) Basic FGF in adult rat brain: cellular distribution and response to entorhinal lesion and fibria-fornix transection. J Neurosci 12:345-355.

Gospodarowicz D, Cheng J, Lui G-M, Baird A, Bohlen P (1984) Isolation of brain fibroblast growth factor by heparin-Sepharose affinity chromatography: identity with pituitary fibroblast growth factor. Proc Natl Acad Sci USA 81:6963-6967.

Hanneken A, Baird A (1992) Immunolocalization of basic fibroblast growth factor: dependence on antibody type and tissue fixation. Exp Eye Res 54:1011-1014.

Healy MA, Herman IM (1992) Density-dependent accumulation of basic fibroblast growth factor in the subendothelial matrix. Eur J Cell Biol 59:56-67.

Herbert JM, Basilico C, Goldfarb M, Haub O, Martin G (1990) Isolation of cDNAs encoding four mouse FGF family members and characterization of their patterns during embryogenesis. Dev Biol 138: 454-463.

Hicks D, Courtois Y (1992) Fibroblast growth factor stimulates photoreceptor differentiation in vitro. J Neurosci 12:2022-2033.

Hoogland PV, Vanderkrans A, Koole FI), Groenewegen HJ (1985) A direct projection from the nucleus oculomotorius to the retina in rats. Neurosci Lett 56:323-328.

Ishigooka H, Aotaki-Keen AE, Hjemeland LM (1992) Subcellular localization of bFGF in human retinal pigment epithelium in vitro. Exp Eye Res 55:203-214.
Itaya SK (1980) Retinal efferents from the pretectal area in the rat. Brain Res 201:436-441.

James GR (1933) Degeneration of ganglion cells following axonal injury. Arch Ophthalmol (Copenh) 9:338-343.

Kimelman D, Abraham JA, Haaparanta T, Palisi TM, Kirschner MW (1988) The presence of fibroblast growth factor in the frog cgg: its role as a natural mesoderm inducer. Science 242:1053-1056.

Labandeira-Garcia JL (1988) The retinopetal system in the rat. Neurosci Res 6:88-95.

Leimfelder PJ (1940) Retrograde degeneration in the optic nerves and tracts. Am J Ophthalmol 23:797-802.

Lillien L, Cepko C' (1992) Control of proliferation in the retina: temporal changes in responsiveness to FGF and TGF- $\alpha$. Development 115:253-266.

Lipton SA, Wagner JA, Madison RD, D'Amore PA (1988) Acidic fibroblast growth factor enhances regeneration of processes by postnatal mammalian retinal ganglion cells in culture. Proc Natl Acad Sci USA 85:2388-2392.

Logan A, Frautschy SA, Gonzalez A-M, Baird A (1992) A time course for the focal elevation of synthesis of basic fibroblast growth factor and one of its high-affinity receptors $(\mathrm{flg})$ following a localized cortical brain injury. J Neurosci 12:3828-3837.

Madison R, Moore MR, Sidman RL (1984) Retinal ganglion cells and axons survive optic nerve transection. Int J Neurosci 23:15-32.

Mascarelli F, Raulais D, Courtois Y (1989) Fibroblast growth factor phosphorylation and receptors in rod outer segments. EMBO I 8:22652273.

Mergia E, Eddy R, Abraham JA, Fiddes JC, Shows TB (1986) The genes for basic and acidic fibroblast growth factors are on different human chromosomes. Biochem Biophys Res Commun 138:644-651.

Mori H, Maki M, Oishi K, Jaye M, Igarashi K, Yoshida O, Hatanaka $M$ (1990) Increased expression of genes for basic fibroblast growth factor and transforming growth factor type $\beta 2$ in human benign prostatic hyperplasia. Prostate 16:71-80.

Morrison RS, Sharma A, DeVellis J, Bradshaw RA (1986) Basic fibroblast growth factor supports the survival of cerebral cortical neurons in primary culture. Proc Natl Acad Sci USA 83:7537-7541.

Noji S, Matsuo T, Koyama E, Yamaai T, Nohno T, Matsuo N, Taniguchi $S$ (1990) Expression pattern of acidic and basic fibroblast growth factor genes in adult rat eyes. Biochem Biophys Res Commun 168:343-349.

Ohno T (1980) The possibility of centrifugal projections to the retina in the rat. Experientia 36:1400-1401.

Otto D, Unsicker K (1990) Basic FGF reverses chemical and morphological deficits in the nigrostriatal system of MPTP-treated mice. J Neurosci 10:1912-1921.

Owusu-Yaw V, Kyle AL, Stell WK (1992) Effects of lesions of the optic nerve, optic tectum and nervus terminalis on rod precursor proliferation in the goldfish retina. Brain Res 576:220-230.

Park CM, Hollenberg MJ (1989) Basic fibroblast growth factor induces retinal regeneration in vivo. Dev Biol 134:201-205.

Perraud F, Labourdette G, Miehe M, Loret C, Sensenbrenner M (1988) Comparison of the morphological effects of acidic and basic fibroblast growth factors on rat astroblasts in culture. J Neurosci Res 20:1-11. Perraud F, Labourdette G, Eclancher F, Sensenbrenner M (1990) Primary cultures of astrocytes from different brain areas of newborn rats and effects of basic fibroblast growth factor. Dev Neurosci 12:11-21.

Plouet J, Mascarelli F, Loret MD, Faure JP, Courtois Y (1988) Regulation of eye derived growth factor binding to membranes by light, ATP or GTP in photoreceptor outer segments. EMBO J 7:373-376.

Schweigerer L, Malerstein B, Neufeld G, Gospodarowicz D (1987) Basic fibroblast growth factor is synthesized in cultured retinal pigment epithelial cells. Biochem Biophys Res Commun 143:934-940.

Shimasaki S, Emoto N, Koba A, Mercado F, Shibata K, Cooksey K, Baird A, Ling N (1988) Complementary DNA cloning and sequencing of rat ovarian basic fibroblast growth factor and tissue distribution study of its mRNA. Biochem Biophys Res Commun 157:256-263.

Shinoda H, Marini AM, Cosi C, Schwartz JP (1989) Brain region and gene specificity of neuropeptide gene expression in cultured astrocytes. Science 245:415-420.

Sievers J, Hausmann B, Unsicker K, Berry M (1987) Fibroblast growth factors promote the survival of adult rat retinal ganglion cells after transection of the optic nerve. Neurosci Lett 76:157-162.

Sternfeld MD, Robertson JE, Shipley GD, Tsai J, Rosenbaum JT (1989) Cultured human retinal pigment epithelial cells express basic fibroblast growth factor and its receptor. Curr Eye Res 8:1029-1037. 
Takami K, Iwane M, Kiyota Y, Miyamoto M, Tsukuda R, Shiosaka S (1992) Increase of basic fibroblast growth factor immunoreactivity and its mRNA level in rat brain following transient forebrain ischemia. Exp Brain Res 90:1-10.

Tsang D, Yew DT, Lam STL (1985) Acute responses of rat retina after optic nerve ligation: a biochemical and histochemical study. Brain Res 336:289-295.

Unsicker K, Reichert PH, Schmidt R, Pettmann B, Labourdette G, Sensenbrenner M (1987) Astroglial and fibroblast growth factors have neurotrophic functions for cultured peripheral and central nervous system neurons. Proc Natl Acad Sci USA 84:5459-5463.

Wagner JA, Kostyk SK (1990) Regulation of neural cell survival and differentiation by peptide growth factors. Curr Opin Cell Biol 2:10501057.

Walicke PA (1988) Basic and acidic fibroblast growth factors have trophic effects on neurons from multiple CNS regions. J Neurosci 8:2618-2627.

Walicke PA, Baird A (1991) Internalization and processing of basic fibroblast growth factor by neurons and astrocytes. $J$ Neurosci 11 : 2249-2258.

Walicke P, Cowan WM, Ueno N, Baird A, Guillemin R (1986) Fibroblast growth factor promotes survival of dissociated hippocampal neurons and enhances neurite extension. Proc Natl Acad Sci USA $83: 3012-3016$ 